\title{
Smear layer and debris removal from dentinal tubules using different irrigation protocols: scanning electron microscopic evaluation, an in vitro study
}

\author{
Hsin-Hui Wang ${ }^{1,2}$, Daniel Sanabria-Liviac ${ }^{3}$, Philippe Sleiman ${ }^{4}$, Samuel O. Dorn ${ }^{1}$ and David E. Jaramillo ${ }^{1 *}$
}

\begin{abstract}
Background: This study investigated the ability of different irrigation protocols to keep dentinal tubules (DT) open and avoid their blockage by the smear layer (SL) during the cleaning and shaping procedure (CSP).

Methods: Twenty-five extracted teeth were divided into five groups $(n=5)$ : group 1, $\mathrm{NaOCl}$ was kept in the canal during instrumentation and then washed out with distilled water, and the canal was irrigated with $\mathrm{NaOCl}$ with EndoVac in between files; group 2, the same procedure as group 1, but NaOCl was replaced by EDTA; group 3, EDTA was kept in the canal during instrumentation and then washed out with distilled water, and the canal was irrigated with $\mathrm{NaOCl}$ with EndoVac in between files; group 4, the same as group 3, but $\mathrm{NaOCl}$ and EDTA were alternated; and group 5 (control), the procedure was the same with group 1, but $\mathrm{NaOCl}$ was replaced by distilled water. A scanning electron microscope was used to evaluate the cleanliness of DT at three different levels of the canals.

Results: Groups 3 and 4 showed better ability to keep DT open during CSP than the other groups. Group 4 only showed statistically significant better results than group 3 at middle third $(P<0.0001)$.

Conclusions: Alternating the use of $\mathrm{NaOCl}$ and EDTA with water in between can keep DT open better and avoid their blockage by SL during CSP compared with the use of $\mathrm{NaOCl}$ or EDTA alone.
\end{abstract}

Keywords: Smear layer, Dentinal tubules, Root canal irrigation

\section{Background}

The present procedures to disinfect the root canal system are primarily by means of chemo-mechanical preparation. However, only 60 to $80 \%$ or less of canal outlines can be prepared circumferentially by instrumentation (Peters 2004). Thus, the disinfection of the remaining untouched area has to rely on chemical irrigation or intracanal medications. More importantly, mechanical preparation leads to the formation of the smear layer (SL) (McComb and Smith 1975; Moodnik et al. 1976; Mader et al. 1984; Torabinejad et al. 2002; Zehnder 2006), which can only be efficiently removed by alternating the use of EDTA and $\mathrm{NaOCl}$ (Goldman et al. 1982; Baumgartner and Mader 1987).

\footnotetext{
* Correspondence: David.E.Jaramillo@uth.tmc.edu

'Department of Endodontics, The University of Texas at Houston School of Dentistry, 7500 Cambridge St., Suite 6417, Houston, TX 77054, USA Full list of author information is available at the end of the article
}

It has been shown that irrigation with 17\% EDTA has an effect on cleaning canal walls (McComb and Smith 1975; Goldman et al. 1982; Baumgartner and Mader 1987). Moreover, both the cleaning and antimicrobial actions are more appreciable when EDTA and $\mathrm{NaOCl}$ are used in combination rather than being used alone (Baumgartner and Mader 1987; Byström and Sundqvist 1985). It is mostly recommended that 17\% EDTA should be applied after cleaning and shaping procedure (CSP) in order to remove the SL before root canal obturation (Baumgartner and Mader 1987). Nevertheless, no definitive irrigation regimen has been built so far.

Alternating the use of EDTA and $\mathrm{NaOCl}$ from the beginning of the CSP has been suggested (De-Deus et al. 2011). Smear layer will become infected and it should be removed. Accordingly, the early use of EDTA may be a prerequisite to establish a protocol for irrigation. In addition, the use of 
water as an intermediate irrigant will help to reduce the interaction between different chemicals inside root canals. This interaction, which can reduce the efficiency of the chemicals, may lead to the formation of undesirable byproducts (Prado et al. 2013).

Therefore, the aim of this study was to investigate the ability of different irrigation sequences to keep the entrances of dentinal tubules (DT) open and avoid the blockage of DT by SL and debris during CSP.

\section{Methods}

The Institutional Review Board of the University of Texas Health Science Center at Houston has approved this research. Twenty-five extracted single-rooted teeth were used in this study. The teeth were cleaned and stored in $1 \times$ phosphate-buffered saline (PBS) solution at room temperature after extraction. The presence of a single and straight canal with an intact and closed apex was verified by taking both the buccolingual and mesiodistal views of radiographs and by examining the teeth under a dental operating microscope (Global Dental Microscopes; Global Surgical Corporation, St. Louis, MO, USA). The teeth with either a wide or calcified canal were discarded. All experimental procedures were manipulated by the same operator (HHW). Each tooth was decoronated at $15 \mathrm{~mm}$ from the anatomic apex. Canal patency was obtained by using a \#10 K-file (Kerr, Orange, CA, USA). In order to achieve a closed system (Tay et al. 2010), the apices were sealed with light-cured flowable composite resin material, and a \#10 K-file was inserted before the apex was sealed to prevent the materials from entering the canal. The roots were then mounted within polyvinylsiloxane (PVS) impression materials so that the entire root surface was covered by the PVS impression material.

The specimens were randomly divided into four experimental groups $(n=5)$ and 1 control group $(n=5)$. All instrumentation procedures were performed with Twisted-Files Adaptive (TFA) Medium/Large (ML) file sets (Kerr, Orange, CA, USA), which contains a series of three files including ML1 (\#25/.08 size/taper), ML2 (\#35/
.06 size/taper), and ML3 (\#50/.04 size/taper). One TFA ML file set was used for each group. For the irrigation procedure, each group had a different irrigation protocol with the aid of EndoVac (Kerr, Orange, CA, USA) as shown in Table 1. The use of EndoVac was to replenish the solutions efficiently and to avoid the formation of an apical vapor lock; its efficacy was not investigated in this study.

\section{Experimental groups}

The root canals were enlarged to size 20 with K-files and filled with irrigant during instrumentation (Table 1). A TFA ML1 file was used to shape the canal to working length; the solution inside the canal was always suctioned out and replenished before the file was re-entered into the canal. This step was repeated until the total $3 \mathrm{~mL}$ of irrigant was injected into the canal. Following the use of the TFA ML1 file, the remaining solution in the canal was washed out by $1 \mathrm{~mL}$ of distilled water.

The root canal was then irrigated by $3 \mathrm{~mL}$ of the second irrigant with the aid of EndoVac. In this step, the MacroCannula was used for the first $1 \mathrm{~mL}$ of the solution and the MicroCannula was used for the last $2 \mathrm{~mL}$ of the solution. The root canal was irrigated with $1 \mathrm{~mL}$ of distilled water to wash out the remaining solution.

The procedure continued with a TFA ML2 file and a TFA ML3 file using the same irrigation sequence. At the end of instrumentation, the liquid inside the canal was suctioned out by the MicroCannula.

\section{Group 1}

Six percent sodium hypochlorite (Vista Dental Products, Racine WI) was used as the irrigant with an intermittent wash of distilled water plus Endovac.

\section{Group 2}

Seventeen percent EDTA (SmearClear, Kerr, Orange CA) was used as the irrigant with an intermittent wash of distilled water plus Endovac.

Table 1 The irrigation sequence of each group

\begin{tabular}{|c|c|c|c|c|c|c|c|c|c|c|c|c|}
\hline Group & $\begin{array}{l}\text { TFA ML1 } \\
\text { (green) }\end{array}$ & & Endovac & & $\begin{array}{l}\text { TFA ML2 } \\
\text { (yellow) }\end{array}$ & & EndoVac & & $\begin{array}{l}\text { TFA ML3 } \\
\text { (red) }\end{array}$ & & EndoVac & \\
\hline 1 & $\begin{array}{l}\mathrm{NaOCl} \\
3 \mathrm{~mL}\end{array}$ & $\begin{array}{l}\text { Water } \\
1 \mathrm{~mL}\end{array}$ & $\begin{array}{l}\mathrm{NaOCl} \\
3 \mathrm{~mL}\end{array}$ & $\begin{array}{l}\text { Water } \\
1 \mathrm{~mL}\end{array}$ & $\begin{array}{l}\mathrm{NaOCl} \\
3 \mathrm{~mL}\end{array}$ & $\begin{array}{l}\text { Water } \\
1 \mathrm{~mL}\end{array}$ & $\begin{array}{l}\mathrm{NaOCl} \\
3 \mathrm{~mL}\end{array}$ & $\begin{array}{l}\text { Water } \\
1 \mathrm{~mL}\end{array}$ & $\begin{array}{l}\mathrm{NaOCl} \\
3 \mathrm{~mL}\end{array}$ & $\begin{array}{l}\text { Water } \\
1 \mathrm{~mL}\end{array}$ & $\begin{array}{l}\mathrm{NaOCl} \\
3 \mathrm{~mL}\end{array}$ & $\begin{array}{l}\text { Water } \\
1 \mathrm{~mL}\end{array}$ \\
\hline 2 & $\begin{array}{l}\text { EDTA } \\
3 \mathrm{~mL}\end{array}$ & $\begin{array}{l}\text { Water } \\
1 \mathrm{~mL}\end{array}$ & $\begin{array}{l}\text { EDTA } \\
3 \mathrm{~mL}\end{array}$ & $\begin{array}{l}\text { Water } \\
1 \mathrm{~mL}\end{array}$ & $\begin{array}{l}\text { EDTA } \\
3 \mathrm{~mL}\end{array}$ & $\begin{array}{l}\text { Water } \\
1 \mathrm{~mL}\end{array}$ & $\begin{array}{l}\text { EDTA } \\
3 \mathrm{~mL}\end{array}$ & $\begin{array}{l}\text { Water } \\
1 \mathrm{~mL}\end{array}$ & $\begin{array}{l}\text { EDTA } \\
3 \mathrm{~mL}\end{array}$ & $\begin{array}{l}\text { Water } \\
1 \mathrm{~mL}\end{array}$ & $\begin{array}{l}\text { EDTA } \\
3 \mathrm{~mL}\end{array}$ & $\begin{array}{l}\text { Water } \\
1 \mathrm{~mL}\end{array}$ \\
\hline 3 & $\begin{array}{l}\text { EDTA } \\
3 \mathrm{~mL}\end{array}$ & $\begin{array}{l}\text { Water } \\
1 \mathrm{~mL}\end{array}$ & $\begin{array}{l}\mathrm{NaOCl} \\
3 \mathrm{~mL}\end{array}$ & $\begin{array}{l}\text { Water } \\
1 \mathrm{~mL}\end{array}$ & $\begin{array}{l}\text { EDTA } \\
3 \mathrm{~mL}\end{array}$ & $\begin{array}{l}\text { Water } \\
1 \mathrm{~mL}\end{array}$ & $\begin{array}{l}\mathrm{NaOCl} \\
3 \mathrm{~mL}\end{array}$ & $\begin{array}{l}\text { Water } \\
1 \mathrm{~mL}\end{array}$ & $\begin{array}{l}\text { EDTA } \\
3 \mathrm{~mL}\end{array}$ & $\begin{array}{l}\text { Water } \\
1 \mathrm{~mL}\end{array}$ & $\begin{array}{l}\mathrm{NaOCl} \\
3 \mathrm{~mL}\end{array}$ & $\begin{array}{l}\text { Water } \\
1 \mathrm{~mL}\end{array}$ \\
\hline 4 & $\begin{array}{l}\mathrm{NaOCl} \\
3 \mathrm{~mL}\end{array}$ & $\begin{array}{l}\text { Water } \\
1 \mathrm{~mL}\end{array}$ & $\begin{array}{l}\text { EDTA } \\
3 \mathrm{~mL}\end{array}$ & $\begin{array}{l}\text { Water } \\
1 \mathrm{~mL}\end{array}$ & $\begin{array}{l}\mathrm{NaOCl} \\
3 \mathrm{~mL}\end{array}$ & $\begin{array}{l}\text { Water } \\
1 \mathrm{~mL}\end{array}$ & $\begin{array}{l}\text { EDTA } \\
3 \mathrm{~mL}\end{array}$ & $\begin{array}{l}\text { Water } \\
1 \mathrm{~mL}\end{array}$ & $\begin{array}{l}\mathrm{NaOCl} \\
3 \mathrm{~mL}\end{array}$ & $\begin{array}{l}\text { Water } \\
1 \mathrm{~mL}\end{array}$ & $\begin{array}{l}\text { EDTA } \\
3 \mathrm{~mL}\end{array}$ & $\begin{array}{l}\text { Water } \\
1 \mathrm{~mL}\end{array}$ \\
\hline 5 & $\begin{array}{l}\text { Water } \\
3 \mathrm{~mL}\end{array}$ & $\begin{array}{l}\text { Water } \\
1 \mathrm{~mL}\end{array}$ & $\begin{array}{l}\text { Water } \\
3 \mathrm{~mL}\end{array}$ & $\begin{array}{l}\text { Water } \\
1 \mathrm{~mL}\end{array}$ & $\begin{array}{l}\text { Water } \\
3 \mathrm{~mL}\end{array}$ & $\begin{array}{l}\text { Water } \\
1 \mathrm{~mL}\end{array}$ & $\begin{array}{l}\text { Water } \\
3 \mathrm{~mL}\end{array}$ & $\begin{array}{l}\text { Water } \\
1 \mathrm{~mL}\end{array}$ & $\begin{array}{l}\text { Water } \\
3 \mathrm{~mL}\end{array}$ & $\begin{array}{l}\text { Water } \\
1 \mathrm{~mL}\end{array}$ & $\begin{array}{l}\text { Water } \\
3 \mathrm{~mL}\end{array}$ & $\begin{array}{l}\text { Water } \\
1 \mathrm{~mL}\end{array}$ \\
\hline
\end{tabular}




\section{Group 3}

Seventeen percent EDTA was used as the first irrigant during shaping of the canal, and 6\% sodium hypochlorite $(\mathrm{NaOCl})$ was used as the second irrigant. Distilled water and EndoVac was used after each solution.

\section{Group 4}

Six percent $\mathrm{NaOCl}$ was used as the first irrigant during shaping of the canal, and 17\% EDTA was used as the second irrigant. Distilled water and EndoVac was used after each solution.

\section{Group 5}

Distilled water was used as the only irrigant.

\section{Preparation for scanning electron microscopy}

A scanning electron microscope (SEM) was used to evaluate the cleanliness of DT on the instrumented canal wall surface. Each root was removed from the PVS impression material and prepared for SEM observation. In order to facilitate the splitting of the roots into halves, two opposing grooves were engraved along the buccal and lingual root surface without penetration into the root canals using a diamond disc under copious water cooling. The roots were then split into halves by a chisel, rinsed with distilled water, and fixed in $4 \%$ formalin for $24 \mathrm{~h}$. The specimens were then dehydrated in sequence with $80 \%$ alcohol for $15 \mathrm{~min}, 90 \%$ alcohol for $15 \mathrm{~min}$, and $100 \%$ alcohol for $20 \mathrm{~min}$. Following the dehydration, the specimens were mounted on aluminum stubs, sputter-coated with platinum, and observed using a SEM (Nova NanoSEM 230; FEI, Hillsboro, OR, USA). Three images showing the canal wall surface at $\times 100, \times 1000$, and $\times 2000$ magnification respectively were taken from the apical, middle, and coronal portion of each half of the roots. A total of 450 micrographs of the canal wall surface were taken.

\section{Evaluation of smear layer and debris removal from dentinal tubules}

The 150 images showing the canal wall surface from three different levels of the canal at $\times 2000$ magnification were evaluated for the cleanliness of DT on the instrumented canal wall surface. The image processing and analysis software ImageJ (version $1.50 \mathrm{e}$; National Institutes of Health, Bethesda, MD, USA) was used to examine the total percentage of the area occupied by the open DT. For image analysis, the images from group 5 served as the standard images, then the software compared these standard images with those images from the other groups and calculated the total area with the open DT, and the results were expressed as a percentage. Statistical analysis was performed using one-way analysis of variance (one-way ANOVA) along with Tukey's multiple comparison test to compare the cleanliness of DT in different groups at each level of the canals. The KruskalWallis test along with Dunn's multiple comparison test was used to compare the cleanliness of DT at different levels in each group $(P<0.05)$.

\section{Results}

One-way ANOVA and Tukey's multiple comparison test showed significant difference in terms of the cleanliness of DT between different groups at each level of the canals (Fig. 1). Groups 1 and 5 showed the least percentage of the area occupied by the open DT; there was no statistically significant difference between groups 1 and $5(P>0.05)$ at all three levels. Generally, groups 3 and 4 revealed higher percent values of the area than the other groups. The value of group 3 was significantly higher than groups 1, 2, and 5 at the coronal third; the value of group 4 was significantly higher than groups 1,2 , and 5 at the apical third $(P<0.05)$. The difference between groups 3 and 4 was not statistically significant at the coronal and apical third $(P>0.05)$; however, group 4 exhibited a significantly higher percentage of the area occupied by the open DT than group 3 at the middle level of the canals $(P<0.05)$.

The results of the Kruskal-Wallis test and Dunn's multiple comparison test also showed significant difference between different levels of the canals in all groups except that in group 5 (Fig. 1). In group 5, there was no significant difference in regard to the cleanliness of DT among the apical, middle, and coronal level of the canals. Our results revealed a significant difference in that the area with the open DT at the apical third was less than that at either the middle or coronal third in groups 1,2 , and $4(P<0.05)$, while there was no significant difference between the middle and coronal level $(P>0.05)$. In group 3 , the difference between the apical third and middle third was not statistically significant, and the percentage of the open DT was higher at coronal level than at apical and middle level $(P<0.05)$.

Figure 2 exhibits the representative SEM micrographs in all groups. No DT could be observed on the canal wall surface in groups 1 (only $\mathrm{NaOCl}$ was used) and 5, and the specimens in both groups were characterized by the presence of SL coating the whole canal wall surface. In group 2 (only EDTA was used), only a few of DT could be seen with patches of SL and debris partially coating the canal wall surface; most of the entrances of dentinal tubules were obstructed by smeared materials. The features of micrographs from groups 3 and 4 (the combined use of $\mathrm{NaOCl}$ and EDTA) were very similar: they both showed the clean canal wall surface along with the orifices of DT exposed clearly without being covered by SL, whereas some scarce debris still remained on the surface even inside DT. 


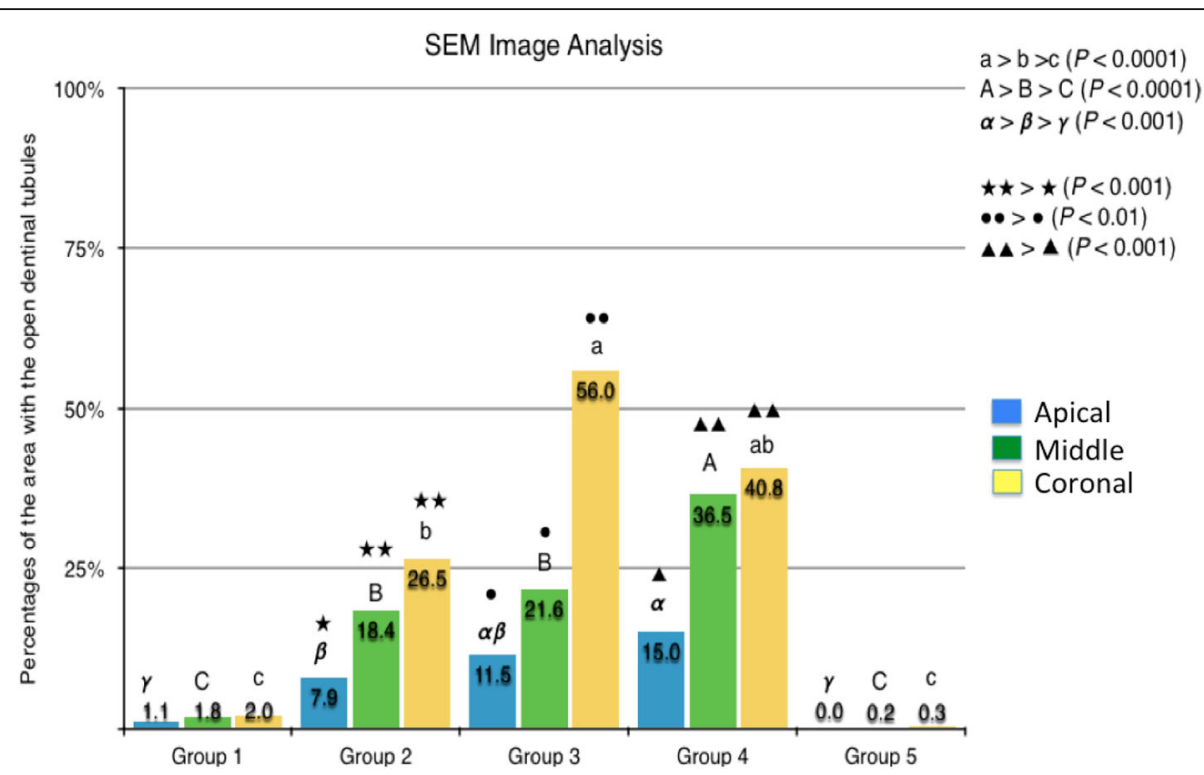

Fig. 1 The result of SEM image analysis. The chart illustrated the statistical result of SEM image analysis. The blue, green, and yellow bar corresponded to the apical middle and coronal level of the canals. The characters $a, b$, and $c$ indicated the statistical difference between each group at the coronal third of the canals $(P<0.0001)$. The characters $A, B$, and $C$ indicated the statistical difference between each group at the middle third of the canals $(P<0.0001)$. The characters $\alpha, \beta$, and $\gamma$ indicated the statistical difference between each group at the apical third of the canals $(P<0.001)$. The number of the symbol black star represents the statistical difference between the apical, middle, and coronal level of the canals in group $2(P<0.001)$. The number of the symbol black circle represented the statistical difference between the apical, middle, and coronal level of the canals in group $3(P<0.01)$. The number of the symbol black triangle represented the statistical difference between the apical, middle, and coronal level of the canals in group $4(P<0.001)$

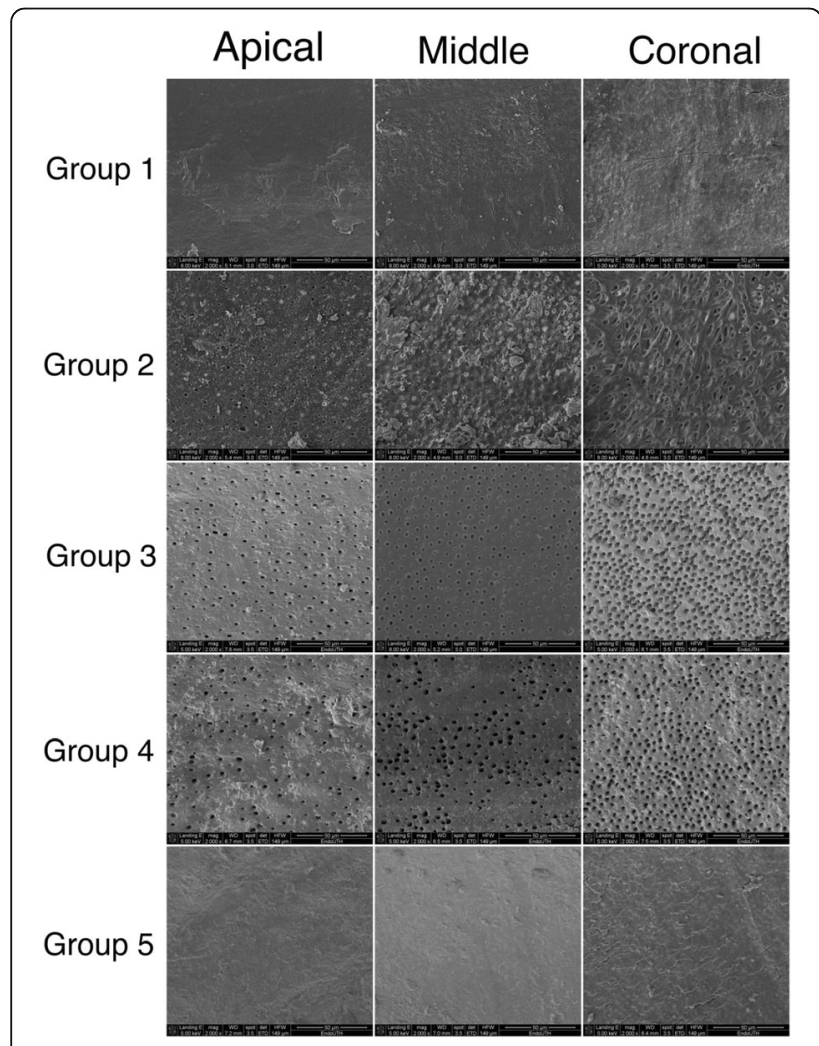

Fig. 2 The representative SEM micrographs in each group

\section{Discussion}

The main purpose of this research was to seek an irrigation protocol which can keep the entrances of DT open and avoid their blockage by SL and debris during CSP. Our results showed that alternating the use of $\mathrm{NaOCl}$ and EDTA with distilled water in between (groups 3 and 4) was more capable of preventing the orifices of DT from being blocked by $\mathrm{SL}$ than using $\mathrm{NaOCl}$ or EDTA alone (groups 1 and 2). The images in group 1, which only used $\mathrm{NaOCl}$ for irrigation as most clinicians do routinely, revealed that there was SL spread over the canal wall surface and no open DT were present. This outcome indicated that the effectiveness of $\mathrm{NaOCl}$ penetration into DT to eliminate the bacteria hiding inside was reduced since most of the entrances have been obstructed by SL and debris during instrumentation (Torabinejad et al. 2002, Goldman et al. 1982, Schoeffel 2008). A previous study showed that the packed material inside DT had a segmented manifestation, which might result from the incremental packing of smeared material and debris during instrumentation (Zehnder 2006). This phenomenon signified that the smeared materials and debris might be too deep to be removed.

The smear layer not only can be colonized by bacteria and protect the existing biofilms adhering to canal walls but also may prevent the penetration of intracanal irrigants and medications into the DT harboring microorganisms. Aside from its potential contamination, SL may interfere with the adaptation between root canal filling materials and 
canal walls and then lead to microleakage (Goldman et al. 1982. Baumgartner and Mader 1987). On the other hand, some investigators hold the opposite opinion. The suggestion is that if bacterial contamination occurred after canal preparation and disinfection, the presence of SL might be able to prevent bacteria from entering into DT. The study from Drake et al. (1994) showed that a greater than tenfold higher number of bacteria colonized in DT without being covered by SL compared with those covered by an intact smear layer. Nevertheless, SL itself contains bacteria (Goldman et al. 1982), and the existence of residual bacteria in root canal system is always the primary concern in endodontic treatment. It has been shown that bacterial persistence at the filling stage is a risk factor for apical periodontitis (McComb and Smith 1975). To remove SL can contribute to the thorough disinfection of root canal system and ensure the tight adaptation of root canal filling materials to canal walls (Goldman et al. 1982; Baumgartner and Mader 1987), which is imperative for prolonging the longevity and achieving a favorable outcome of endodontic treatment. Previous studies evaluated the influence of SL on the antimicrobial activity of different disinfecting irrigants (Wang et al. 2013; Morago et al. 2016). Both of the authors reported that SL reduced the effectiveness of $\mathrm{NaOCl}$ against Enterococcus faecalis in infected DT (Wang et al. 2013, Morago et al. 2016). The weaker effect of $\mathrm{NaOCl}$ could result from the formation of a barrier by SL so that less irrigants could pass through and also the irrigants might be inactivated in the process of penetration (Morago et al. 2016). Wang et al. (2013) further suggested that SL should be removed to optimize the effect of disinfecting solutions against bacteria in the DT in an infected root canal (Morago et al. 2016).

The present study was aiming to establish an irrigation sequence to prevent SL from accumulating into DT and therefore maximize the antimicrobial action of endodontic irrigants during CSP. In our result, it was evident that alternating the use of $\mathrm{NaOCl}$ and EDTA with water in between can better remove SL and keep DT open during CSP than using $\mathrm{NaOCl}$ or EDTA alone. However, whether $\mathrm{NaOCl}$ or EDTA should be kept in the root canal with the use of rotary instruments was not determined in this study since the difference between groups 3 and 4 was not significant except at the middle level of the canals. Both $\mathrm{NaOCl}$ and EDTA can benefit the removal of SL and debris during instrumentation, so further investigation for the role of $\mathrm{NaOCl}$ and EDTA with the use of rotary instruments may be necessary. At present, a variety of rotary instruments have been developed which are shortening the chair time needed to prepare root canals, which means more clinical time is available for clinicians to perform a thorough chemical disinfection during endodontic treatment. More studies will be needed to investigate the efficacy of the aid of different irrigation systems (such as ultrasonic irrigation, photon-induced photoacoustic streaming, and multisonic ultracleaning system) and the combined use of $\mathrm{NaOCl}$ and EDTA with water in between to keep DT open during CSP.

\section{Conclusions}

Under the conditions of the current study, alternating the use of $6 \% \mathrm{NaOCl}$ and 17\% EDTA with water in between showed significantly better ability to keep the entrances of dentinal tubules open and avoid the blockage of dentinal tubules by the smear layer and debris during the CSP compared with the use of $6 \% \mathrm{NaOCl}$ or $17 \%$ EDTA alone. The result of this pilot study emphasized the importance of the early use of 17\% EDTA from the beginning of CSP.

\section{Acknowledgements \\ Dr. David E Jaramillo Serves as a consultant for Kerr Endodontics.}

\section{Authors' contributions}

HHW performed the selection of teeth, sectioning of the root, cleaning and shaping and irrigation portion of the experiment and sectioning of the roots. Conducted scanning under SEM. DSL performed the evaluation of smear layer removal by using the ImageJ software. PS search for literature and desing the methodology for the present study. SOD helped in the writing of mansucript of the paper and helped to developed the discussion portion of the paper. DEJ Desing the study, mentor Hsin-Hiu Wang how to select and section teeth, Irrigation and instrumentation the root canals, the preparation of specimen for SEM and conducted the scanning of specimens under SEM. All authors read and approved the final manuscript.

Ethics approval and consent to participate

The Institutional Review Board of the University of Texas Heatlh Science Center at Houston has approved this research.

\section{Competing interests}

The authors declare that they have no competing interests.

\section{Publisher's Note}

Springer Nature remains neutral with regard to jurisdictional claims in published maps and institutional affiliations.

\section{Author details}

'Department of Endodontics, The University of Texas at Houston School of Dentistry, 7500 Cambridge St., Suite 6417, Houston, TX 77054, USA. ²Division of Endodontics, Department of Oral Medicine, Taipei Medical

University-Municipal Wan Fang Hospital, Taipei, Taiwan. ${ }^{3}$ University of Inca Garcilaso de la Vega, Lima, Peru. ${ }^{4}$ Dental School, The Lebanese University, Beirut, Lebanon.

Received: 9 June 2017 Accepted: 6 July 2017

Published online: 17 July 2017

\section{References}

Baumgartner JC, Mader CL. A scanning electron microscopic evaluation of four root canal irrigation regimens. J Endod. 1987;13:147-57.

Byström A, Sundqvist G. The antibacterial action of sodium hypochlorite and EDTA in 60 cases of endodontic therapy. Int Endod J. 1985:18:35-40.

De-Deus G, Reis C, Paciornik S. Critical appraisal of published smear layer-removal studies: methodological issues. Oral Surg Oral Med Oral Pathol Oral Radiol Endod. 2011;112(4):531-43.

Drake DR, Wiemann AH, Rivera EM, Walton RE. Bacterial retention in canal walls in vitro: effect of smear layer. J Endod. 1994;20:78-82.

Goldman M, Goldman LB, Cavaleri R, Bogis J, Lin PS. The efficacy of several endodontic irrigating solutions: a scanning electron microscopic study: part 2. J Endod. 1982;8:487-92. 
Mader CL, Baumgartner JC, Peters DD. Scanning electron microscopic investigation of the smeared layer on root canal walls. J Endod. 1984;10:477-83.

McComb D, Smith DC. A preliminary scanning electron microscopic study of root canals after endodontic procedures. J Endod. 1975;1:238-42.

Moodnik RM, Dorn SO, Feldman MJ, Levey M, Borden BG. Efficacy of biomechanical instrumentation: a scanning electron microscopic study. J Endod. 1976;2:261-6

Morago A, Ordinola-ZapataR F-LCM, Baca P, Ruiz-Linares M, Arias-Moliz MT. Influence of smear layer on the antimicrobial activity of a sodium hypochlorite/etidronic acid irrigating solution in infected dentin. J Endod. 2016:42:1647-50

Peters OA. Current challenges and concepts in the preparation of root canal systems: a review. J Endod. 2004;30:559-67.

Prado M, Santos Junior HM, Rezende CM, Pinto AC, Faria RB, Simao RA, et al. Interactions between irrigants commonly used in endodontic practice: a chemical analysis. J Endod. 2013;39:505-10.

Schoeffel GJ. The EndoVac method of endodontic irrigation, part 2-efficacy. Dent Today. 2008;27:82-7.

Tay FR, Gu LS, Schoeffel GJ, Wimmer C, Susin L, Zhang K, et al. Effect of vapor lock on root canal debridement by using a side-vented needle for positivepressure irrigant delivery. J Endod. 2010;36:745-50.

Torabinejad M, Handysides R, Khademi AA, Bakland LK. Clinical implications of the smear layer in endodontics: a review. Oral Surg Oral Med Oral Pathol Oral Radiol Endod. 2002;94:658-66.

Wang Z, Shen Y, Haapasalo M. Effect of smear layer against disinfection protocols on Enterococcus faecalis-infected dentin. J Endod. 2013;39:1395-400.

Zehnder M. Root canal irrigants. J Endod. 2006;32:389-98.

\section{Submit your manuscript to a SpringerOpen ${ }^{\circ}$ journal and benefit from:}

- Convenient online submission

- Rigorous peer review

- Open access: articles freely available online

- High visibility within the field

- Retaining the copyright to your article

Submit your next manuscript at $\gg$ springeropen.com 